Article

\title{
Growth Performance of Jatropha curcas Cultivated on Local Abandoned Bauxite Mine Soil
}

\author{
Lim Mingyuan ${ }^{1}$, Abd Wahid Samsuri ${ }^{2}$, Mohd Yunus Shukor ${ }^{3}$ (I) and Lai Yee Phang ${ }^{1, *}$ \\ 1 Department of Bioprocess Technology, Faculty of Biotechnology and Biomolecular Sciences, \\ Universiti Putra Malaysia, UPM Serdang, Selangor 43400, Malaysia; Ming_OnATrip@live.com \\ 2 Department of Land Management, Faculty of Agriculture, Universiti Putra Malaysia, UPM Serdang, \\ Selangor 43400, Malaysia; samsuriaw@upm.edu.my \\ 3 Department of Biochemistry, Faculty of Biotechnology and Biomolecular Sciences, Universiti Putra Malaysia, \\ UPM Serdang, Selangor 43400, Malaysia; mohdyunus@upm.edu.my \\ * Correspondence: phanglaiyee@upm.edu.my
}

Received: 23 July 2020; Accepted: 14 September 2020; Published: 8 October 2020

\begin{abstract}
Lack of regulation in bauxite mining has caused land contamination in Malaysia. Land rehabilitation requires plants with excellent adaptability to adverse conditions. Inedible, economical viable crops with environmental co-benefits, like phytoremediation, are preferred. In this study, Jatropha curcas was evaluated for its growth performance in bauxite mine soil. Topsoil and exposed subsoil were sampled from a bauxite mine at Bukit Goh, Kuantan and used for growing J. curcas for 90 days under greenhouse conditions. The soil physicochemical properties, plant growth parameters (increase in number of leaves, plant height, and basal diameter), and oil yield were determined. The findings showed that the mine soils had lower nutrient status than unmined soil as reflected by the total $\mathrm{C}, \mathrm{N}, \mathrm{P}$, and $\mathrm{K}$ values. $\mathrm{Al}, \mathrm{Fe}$, and $\mathrm{Pb}$ were relatively high in topsoil and subsoil. Plants grown in both mine soils recorded significantly lower increases in plant height and basal diameter but higher increases in number of leaves than that of nursery soil. Oil yield was significantly different between the plants grown in subsoil (46.54\%) and topsoil (41.65\%). The study demonstrated that $J$. curcas has the potential to be cultivated as an alternative crop in bauxite mine soil.
\end{abstract}

Keywords: Jatropha curcas; growth performance; land rehabilitation; revegetation; bauxite mine soil; Jatropha oil

\section{Introduction}

The bauxite industry in Malaysia experienced a surge in January 2014, particularly in Kuantan, the state capital of Pahang. Bauxite is the ore that contains aluminum in its natural form, namely alumina $\left(\mathrm{Al}_{2} \mathrm{O}_{3}\right)$ at roughly $50 \%$ to $70 \%$ [1]. Bauxite is found 1 or $2 \mathrm{~m}$ below the soil surface and commonly mined with the strip mining (opencast mining) method by removing the overlying soil layer [2]. This leads to disruption of soil aggregates and loss of organic matter, including vegetation and microorganisms [3]. Nutrient cycling is impaired by the perturbation to the soil microbial community via opencast mining [4]. Therefore, removed topsoil is in risk of deterioration if proper mining and storage practices are not applied [5]. Topsoil stockpiles can be seen around the bauxite mining site at Bukit Goh, Kuantan. This leaves the non-nutritive subsoil exposed, which will further hinder any future revegetation process. Besides, disruption of soil structure also increases the risk of leaching of soil nutrients and trace elements [3]. As reported by Kusin et al. [2], the water and sediments at several locations in Kuantan were found to contain heavy metals such as aluminum ( $\mathrm{Al})$, iron ( $\mathrm{Fe})$, copper $(\mathrm{Cu})$, manganese $(\mathrm{Mn})$, lead $(\mathrm{Pb})$, zinc $(\mathrm{Zn})$, and especially arsenic (As) at concerning levels exceeding recommended values. 
Environmental degradation is inevitable without a proper regulation to the mining activities. Conventional soil remediation methods such as soil replacement and soil washing are costly and unsustainable [6]. High cost is required for high labor work in soil replacement methods, while the washing extractants used in soil washing methods imposes a secondary environmental risk [7]. Over the years, phytoremediation has been proposed as an alternative solution with a holistic approach. It is regarded as a less invasive method with environmental co-benefits [8]. Besides reducing the risk of ancillary environmental impacts, phytoremediation also provides opportunities for long term financial returns by repurposing wastelands [9]. The effectiveness of phytoremediation depends largely on the ability of the plant to survive under adverse environmental conditions. Ideally, food crops are avoided to prevent contamination to the food chain [10]. Among the proposed phytoremediation plants over the years are Brassica juncea [11], giant reed [12], and Thlaspi caerulescens [13]. Nevertheless, phytoremediation commonly faces challenges such as low biomass, slow growth rate, postharvest management of treated biomass, and the introduction of invasive plant species [14].

In Malaysia, land rehabilitation of an abandoned bauxite mine at Pengerang, Johor using oil palm was met with challenges, as the plants showed symptoms of water stress and nutrient disorder [15]. Additionally, the palm oil produced from the site might contain concerning levels of contaminants that will pose health risks if consumed. Jatropha curcas might offer an alternative solution. J. curcas is a small perennial tree that originated from Latin America, but has spread globally throughout the tropical and subtropical regions [16]. Its widespread distribution can be credited to its favorable characteristics, such as easy propagation, rapid growth, hardy nature, and drought tolerance [17]. J. curcas is an underutilized plant, yet it has potential for sustainable industrial use. It is regarded as a multipurpose plant as its products can be used for various functions, such as in hedges, fertilizer, pesticide, soap, medicine, and as an energy source [18]. As opposed to oil palm, J. curcas yields inedible oil that acts as biofuel feedstock. J. curcas-derived biodiesel is sought after for its higher performance and lower environmental impact compared to other oil derived diesel fuels [19]. Besides, by being a drought-tolerant and inedible crop, J. curcas avoids competition for arable land with food crops [19]. At the same time, J. curcas has shown promising value as a phytoremediation plant in a wide range of applications, like treating waste materials generated by anthropogenic activities, such as those used for lubricating oil, sludge, fly ash, and sawdust, in addition to remediating a derelict paddy field in situ [20-24].

It is essential to investigate the growth and yield aspects as J. curcas can be an economically viable biofuel crop in marginal soils [25]. Agricultural activities centering around J. curcas, such as biofuel production, are able to create job opportunities and accelerate rural development while adhering to environmental commitments, like the cutback on greenhouse gas emission and carbon sequestration [18]. Hence, in this study, Jatropha curcas was chosen as the test plant to be cultivated on bauxite mine soil. It was expected that J. curcas would be able to show good growth performance and oil yield in marginal soil like bauxite mine soil. The physicochemical properties of bauxite mine topsoil and subsoil were examined. Then, the growth performance of J. curcas on these soils was evaluated and compared to that of nursery soil. Lastly, oil yield of the plants was analyzed to determine any relationship with the heavy metal concentration in the soil.

\section{Materials and Methods}

\subsection{Study Location}

This study was conducted in a $100 \mathrm{~m}^{2}$ greenhouse located in Taman Pertanian Universiti, Universiti Putra Malaysia, Serdang ( $2^{\circ} 58^{\prime} 54.1^{\prime \prime} \mathrm{N} 101^{\circ} 42^{\prime} 49.2^{\prime \prime}$ E) from January 2018 to April 2018. Mean monthly temperature in Serdang was $26.9^{\circ} \mathrm{C}$ and average annual rainfall was $2369 \mathrm{~mm}$ during the time when the experiment was carried out. 


\subsection{Soil Sample}

The soils used in this study were collected from FELDA Bukit Goh, Kuantan $\left(3^{\circ} 55^{\prime} 09.8^{\prime \prime} \mathrm{N}\right.$ $103^{\circ} 14^{\prime} 58.0^{\prime \prime} \mathrm{E}$ ), where bauxite mining was carried out actively until the implementation of a moratorium issued by the government starting from January 2016 to April 2019. Topsoil up to $20 \mathrm{~cm}$ deep and the exposed lower horizon subsoil were sampled. The subsoil was lying about $6 \mathrm{~m}$ deep underground before being exposed due to the mining activity. Around $300 \mathrm{~kg}$ of soil was packed into gunny bags and transported to UPM.

\subsection{Test Plant}

Three months old J. curcas seedlings were purchased from the supplier BIOTECH EQUIPMENT \& ENTERPRISE in Johor. The seedlings were maintained for a week as an acclimatization process with a daily irrigation of $200 \mathrm{~mL}$ water before being transplanted to the evaluated soils in black polybags.

\subsection{Pot Experimental Design}

J. curcas seedlings were transferred to the sampled topsoil and subsoil in polybags, limiting to only one plant per bag. Each polybag held around $20 \mathrm{~kg}$ of soil. Apart from the soils from FELDA Bukit Goh, nursery soil was also acquired to be used as a control in pot experiment. Then, the plants were aligned according to randomized complete block design (RCBD) with five replicates per treatment in the greenhouse. The plants were grown in a greenhouse environment where only natural sunlight was received and excessive water from rainfall was prevented. The average humidity was at $80 \%$ during the pot experiment period. For irrigation, a $200 \mathrm{~mL}$ of water was supplied to each plant every two days. Common agriculture practice like minimal fertilizer and pesticide was also applied to ensure that the plants were not affected by other external factors, such as pests and diseases. The plants were grown for 90 days before they were harvested for analysis.

\subsection{Soil Characterization}

The physicochemical properties of both topsoil and subsoil were determined. The following characterization tests were modified based on the methods described in Soil Analysis: Handbook of Reference Methods [26], unless stated otherwise. Soil pH and electrical conductivity (EC) were determined by mixing the soil with potassium chloride $(\mathrm{KCl})$ and deionized water, respectively, at the ratio of $1 \mathrm{~g}: 2.5 \mathrm{~mL}$. Cation exchange capacity (CEC); total carbon (C); and total nitrogen, phosphorus, and potassium (NPK) value were evaluated at the Department of Land Management, Faculty of Agriculture, UPM. CEC was estimated by preparing the soil sample using the shaking method with $1 \mathrm{~N}$ ammonium acetate $\left(\mathrm{NH}_{4} \mathrm{OAc}\right)$ as the leaching agent prior to analysis using the atomic absorption spectrometer (AAS). Total available $\mathrm{P}$ and extractable $\mathrm{K}$ were determined by Bray 2 method and leaching method using ammonium acetate, respectively. Meanwhile, total $\mathrm{C}$ and $\mathrm{N}$ were determined by using the Dumas method modified from Jimenez et al. [27].

Bioavailable heavy metal concentration of the soils was extracted by using Mehlich 1 solution and sent to the inductively coupled plasma-optical emission spectrometer (ICP-OES) for analysis. Mehlich 1 solution was prepared by mixing $0.05 \mathrm{~N}$ hydrochloric acid $(\mathrm{HCl})$ and $0.025 \mathrm{~N}$ sulfuric acid $\mathrm{H}_{2} \mathrm{SO}_{4}$ together with deionized water. A $5 \mathrm{~g}$ of soil sampled was then mixed in $20 \mathrm{~mL}$ of Mehlich 1 solution and shaken for $5 \mathrm{~min}$ prior to filtration. The elements in the filtrate were determined by using PerkinElmer Optima 8300 ICP-OES made in USA. The targeted elements in this study were aluminium $(\mathrm{Al})$, arsenic $(\mathrm{As})$, cadmium $(\mathrm{Cd})$, chromium $(\mathrm{Cr})$, iron $(\mathrm{Fe})$, lead $(\mathrm{Pb})$ and zinc $(\mathrm{Zn})$.

The soil was sampled to determine $\mathrm{pH}, \mathrm{EC}$, and microbial population every 30 days throughout the pot experiment, whereas $\mathrm{CEC}$, total $\mathrm{C}, \mathrm{N}$, available $\mathrm{P}$, and extractable $\mathrm{K}$ were examined before and after the pot experiment. For every analysis, the soil samples were air-dried, ground, and sieved through a $2 \mathrm{~mm}$ sieve before going through each analytical procedure, respectively. 


\subsection{Plant Analysis}

The plants were subjected to growth measurement every 15 days during the pot experiment. Growth measurement parameters included increase in number of leaves, plant height, and basal diameter [28]. The number of leaves was calculated by only counting the healthy leaves that did not exhibit signs of wilting. The plant height was measured using a measuring tape, whereas the basal diameter was measured with digital calipers. The root biomass was also calculated by measuring the dry weight of the root after the plants were harvested.

\subsection{Seed and Oil Yield}

Seed yield was also estimated by collecting matured seeds from ripe yellow fruits during the pot experiment period. Number of seeds and seed weight were calculated to compare the seed yield between the treatments. Harvested seeds were used for oil extraction subsequently. The seeds were deshelled to separate the kernel. The kernel was ground and dried to remove excess moisture. After that, the seed oil was extracted by using the method described by [29] with some modifications. A $10 \mathrm{~g}$ of ground seed kernel was extracted with $150 \mathrm{~mL}$ of $\mathrm{n}$-hexane for $4 \mathrm{~h}$ in a Soxhlet extractor. The extracted seed oil was then recovered by removing the n-hexane in a rotary evaporator. Seed oil yield was obtained by using the following equation:

$$
\% \text { oil yield }=\frac{\text { weight of oil extracted }(\mathrm{g})}{\text { weight of seed kernel used }(\mathrm{g})} .
$$

Meanwhile total oil production for each treatment was calculated as follows:

$$
\text { total oil production }(\mathrm{g})=\% \text { oil yield } \times \text { total weight of seed }(\mathrm{g}) \text {. }
$$

\subsection{Statistical Analysis}

Statistical analysis was carried out to determine the statistical significance of the data obtained from the pot experiment. Correlation test was carried out to determine the relationship between total extractable K and other soil physicochemical properties. One-way ANOVA was performed to compare the means between the soil types in terms of plant growth and oil yield. Then, correlation and regression analyses were performed to evaluate the relationship between heavy metal concentration in soil and the plant oil yield.

\section{Results and Discussion}

Table 1 shows the physicochemical properties of the bauxite mine topsoil and subsoil sampled from Bukit Goh in comparison to that of the unmined soil reported by Harris et al. [3]. The results indicated that the soils in Bukit Goh was heavily deprived of nutrients after the mining activity. Generally, subsoil contained lower amounts of soil nutrients compared to topsoil. While both topsoil and subsoil exhibited similar levels of total available $\mathrm{P}$, subsoil lacked substantially in total $C$ content and total extractable $\mathrm{K}$ in comparison to topsoil. For major plant nutrients like total $\mathrm{N}$ and total available $\mathrm{P}$, the findings in this study ranged from $0.01 \%$ to $0.04 \%$ and $4.34 \mu \mathrm{g} / \mathrm{g}$ to $4.56 \mu \mathrm{g} / \mathrm{g}$, respectively. Total C content and total extractable $\mathrm{K}$ level in topsoil were in the range of $0.43 \%$ to $0.45 \%$ and $24.15 \mu \mathrm{g} / \mathrm{g}$ to $70.13 \mu \mathrm{g} / \mathrm{g}$, respectively, while subsoil recorded only traces of total C and $2.21 \mu \mathrm{g} / \mathrm{g}$ to $47.84 \mu \mathrm{g} / \mathrm{g}$ of total extractable K. Topsoil was more acidic with a pH range of 4.83-4.94, whereas subsoil displayed a higher $\mathrm{pH}$ range of 5.81-5.84.

Cation exchange capacity (CEC) is useful for two purposes: soil classification and soil fertility assessment [30]. In this study, topsoil had a CEC range of $5.12 \mathrm{cmol} / \mathrm{kg}$ to $5.31 \mathrm{cmol} / \mathrm{kg}$, while that of subsoil was in the range of $1.65 \mathrm{cmol} / \mathrm{kg}$ to $3.85 \mathrm{cmol} / \mathrm{kg}$. The CEC of both soil types in this study were lower than $7 \mathrm{cmol} / \mathrm{kg}$ of soil, which is indicative of high leaching potential as described by the fertility capability soil classification system (FCC) [31]. The recorded CEC values put topsoil and subsoil into 
the category of mineral, or more precisely kaolinite clay soil, which has CEC values ranging from $3-15 \mathrm{cmol} / \mathrm{kg}$, as opposed to CEC values of organic soil that have a range of $50-100 \mathrm{cmol} / \mathrm{kg}$ [32]. The ability of soil to retain cationic plant nutrients like $\mathrm{Ca}^{2+}, \mathrm{Mg}^{2+}$, and $\mathrm{K}^{+}$reduces as CEC value decreases. Soils with low CEC value are thus prone to nutrient leaching, which leads to low soil fertility.

Table 1. Physicochemical properties of topsoil and subsoil.

\begin{tabular}{cccccc}
\hline & \multicolumn{2}{c}{ Topsoil } & \multicolumn{2}{c}{ Subsoil } & Unmined Soil from Mount \\
Nelson, Jamaica [3]
\end{tabular}

As shown in Table 2, total extractable $\mathrm{K}$ was found to be positively and significantly correlated to CEC, total $\mathrm{N}$ at $p<0.01$, and total $\mathrm{C}$ at $p<0.05$, respectively. On the contrary, total extractable $\mathrm{K}$ was negatively correlated to $\mathrm{pH}$ at $p<0.05$. This is in concurrence with the findings as reported by Saini et al. [33]. CEC reflects the ability of the soil to retain cations like K, which is adsorbed to negatively charged colloids like clay and organic matter in soil [34]. A drastic rise in total extractable K was noticed after 90 days of pot experiment, as illustrated in Table 1. Topsoil and subsoil experienced a 2.90-fold and 21.65-fold increment, respectively. Total amount of $\mathrm{K}$ reserve in the soil can be categorized into two groups, namely nonextractable and extractable K. Extractable K includes plant-available or water-soluble K (which plants can absorb readily) and slowly available or exchangeable K that will be released into the plant-available pool slowly [35]. Nonextractable K is attached to the negatively charged clay interlayer and only released bit by bit by mineral weathering, especially when extractable $\mathrm{K}$ is low [36]. The increase in total extractable $\mathrm{K}$ observed here could be credited to the conversion of nonextractable or slowly available form to the extractable form as the plant-available $\mathrm{K}$ was being taken up by the plants. Increase of extractable and plant-available $\mathrm{K}$ was also associated with plant cultivation and $\mathrm{K}$ fertilization previously $[37,38]$. A considerable decrease in the extractable pool of $\mathrm{K}$ by plant uptake is prevented with the effective releasing of $\mathrm{K}$ from the nonextractable pool [34]. The new total extractable $\mathrm{K}$ level showed a potentially restored soil $\mathrm{K}$ returning to optimum level.

Table 2. Correlation between total extractable K and other soil physicochemical properties.

\begin{tabular}{|c|c|c|c|c|c|c|c|}
\hline & $\begin{array}{c}\text { Total } \\
\text { Extractable } \\
\text { K }\end{array}$ & CEC & Total C & Total N & $\begin{array}{c}\text { Total } \\
\text { Available } \\
\mathbf{P}\end{array}$ & pH & EC \\
\hline Total extractable K & 1.000 & $0.924^{* *}$ & 0.850 * & $0.967^{* *}$ & -0.495 & -0.850 & 0.355 \\
\hline CEC & $0.924 * *$ & 1.000 & $0.957^{* *}$ & 0.964 ** & -0.402 & $-0.964 * *$ & 0.406 \\
\hline Total C & $0.850 *$ & $0.957^{* *}$ & 1.000 & $0.939^{* *}$ & -0.238 & $-0.999 * *$ & 0.638 \\
\hline Total N & $0.967 * *$ & $0.964 * *$ & $0.939 * *$ & 1.000 & -0.368 & $-0.942 * *$ & 0.488 \\
\hline Total available $P$ & -0.495 & -0.402 & -0.238 & -0.368 & 1.000 & 0.236 & 0.065 \\
\hline $\mathrm{pH}$ & $-0.850 *$ & -0.964 & $-0.999 * *$ & $-0.942 * *$ & 0.236 & 1.000 & -0.609 \\
\hline EC & 0.355 & 0.406 & 0.638 & 0.488 & 0.065 & -0.609 & 1.000 \\
\hline
\end{tabular}

Table 3 reveals the concentration of selected heavy metals found in topsoil and subsoil. The targeted heavy metals were selected based on various reports and past studies on the environmental impact of bauxite mining. Al was the most saturated metal found in this study regardless of the soil types. 
A higher concentration was observed in topsoil, i.e., $2613.47 \mathrm{mg} / \mathrm{kg}$ as opposed to the subsoil reading, which notched $1458.00 \mathrm{mg} / \mathrm{kg}$. Al availability was higher in topsoil due to the lower $\mathrm{pH}$ as $\mathrm{Al}$ solubility increases when $\mathrm{pH}$ descends to below 5 [39]. Al is not included in both the Dutch Standard and other similar studies as it occurs in high concentration in the soil naturally [40]. Moreover, since the objective of bauxite mining is to extract $\mathrm{Al}$, past studies might not have placed the focus on the remaining level of $\mathrm{Al}$ in the soil. As had the lowest concentration in both topsoil and subsoil, where it was only found in traces.

Table 3. Heavy metal concentration of topsoil and subsoil.

\begin{tabular}{|c|c|c|c|c|c|c|c|}
\hline \multirow[b]{2}{*}{$\begin{array}{l}\text { Heavy } \\
\text { Metal }\end{array}$} & \multicolumn{7}{|c|}{ Concentration (mg/kg of Soil) } \\
\hline & Topsoil & Subsoil & $\begin{array}{c}\text { Bauxite } \\
\text { Mine Soil in } \\
\text { India [41] }\end{array}$ & $\begin{array}{c}\text { Post-Mining } \\
\text { Bauxite Mine } \\
\text { Topsoil [3] }\end{array}$ & $\begin{array}{c}\text { Post-Mining } \\
\text { Bauxite Mine } \\
\text { Subsoil [3] }\end{array}$ & $\begin{array}{c}\text { Dutch } \\
\text { Target } \\
\text { Value [40] }\end{array}$ & $\begin{array}{c}\text { Dutch } \\
\text { Intervention } \\
\text { Value [40] }\end{array}$ \\
\hline Al & $2613.47 \pm 396.83$ & $1458.00 \pm 287.39$ & $\mathrm{n} / \mathrm{a}$ & $\mathrm{n} / \mathrm{a}$ & $\mathrm{n} / \mathrm{a}$ & $\mathrm{n} / \mathrm{a}$ & $\mathrm{n} / \mathrm{a}$ \\
\hline As & n.d. & n.d. & $\mathrm{n} / \mathrm{a}$ & $\mathrm{n} / \mathrm{a}$ & $\mathrm{n} / \mathrm{a}$ & 29 & 55 \\
\hline Cd & $0.008 \pm 0.004$ & $0.023 \pm 0.020$ & $1060 \pm 1.31$ & $\mathrm{n} / \mathrm{a}$ & $\mathrm{n} / \mathrm{a}$ & 0.8 & 12 \\
\hline $\mathrm{Pb}$ & $101.77 \pm 7.87$ & $58.37 \pm 1.89$ & $742.6 \pm 0.07$ & $\mathrm{n} / \mathrm{a}$ & $\mathrm{n} / \mathrm{a}$ & 85 & 530 \\
\hline $\mathrm{Zn}$ & $1.200 \pm 0.391$ & $1.493 \pm 0.413$ & $827.5 \pm 2.64$ & 2 & 11 & 140 & 720 \\
\hline
\end{tabular}

n/a indicates that data are not available. n.d. means not detectable.

The findings were compared with other similar studies and the Dutch Target and Intervention Values, which are used by many as standard indexes. Overall, the heavy metal concentration in soil differed between this study and other similar studies. The concentration of various heavy metals in the bauxite mine soil from Salem District, India were much higher than the findings in this study. In contrary, the heavy metal level in the post-mining bauxite mine soil on Manchester Plateau in southwestern Jamaica [3], particularly that of Fe and Zn, were found to be lower than the Dutch Target and Intervention Value and also closer to the findings in this study.

The Dutch Target and Intervention Value provides reference levels for environmental contaminants in aid of the investigation and cleanup process. Target value indicates the optimum level to have sustainable soil quality, whereas intervention value represents the level above which serious contamination occurs. All the selected heavy metals in this study were found to be well below the Dutch Target and Intervention Values, except for $\mathrm{Pb}$ in topsoil, which exceeded the target value but not the intervention value. The result suggested that the topsoil contained $\mathrm{Pb}$ in a concentration close to the optimum level, without causing serious contamination. As, $\mathrm{Cd}, \mathrm{Cr}$, and $\mathrm{Zn}$ were below the target value and thus deemed to be insufficient for a sustainable soil quality. Conversely, the heavy metal concentration found in the bauxite mine soil from Salem District, India exceeded the Dutch Intervention Value and thus was considered as serious soil contamination. The contamination was caused by the accumulation of waste dumping from the processing of bauxite ore [41].

The growth of Jatropha curcas was monitored and measured throughout the pot experiment. Three parameters, namely increase in number of leaves, increase in plant height (\%), and increase in basal diameter (\%), were observed and recorded as depicted in Figure 1. All three parameters experienced a rise across the treatments with varying rate. Overall, plants grown in nursery soil outperformed those grown in topsoil and subsoil, except for the increase in number of leaves. This finding differs from other related studies where they found that J. curcas grown in bauxite mine soil and control had a similar increase in leaf number [42,43]. The trade-off between leaf growth and stem growth can be explained according to the 'leafing intensity premium' hypothesis [44,45]. It states that high leafing intensity is associated with high density of axillary meristems, which will initiate branching. This was clearly demonstrated in plants grown in topsoil and subsoil, where lateral branch developed as opposed to the absence of branching in plants grown in nursery soil (Figure 2). More leaves were developed to meet the higher energy demand as required by branching, conversely the energy of plants grown in nursery soil was mainly invested in stem development (height and 
diameter). The different development strategy observed here could be attributed to the different condition (soil) that the plants were grown in. A higher leafing intensity is commonly followed by a higher fruiting rate, which in turn generates a higher potential fecundity allocation to allow maximum reproductive economy as a response to disadvantageous growing conditions [46].

Nevertheless, subsoil showed an advantage in cultivating J. curcas compared to topsoil. The most evident difference between topsoil and subsoil was found in the increase of plant height, where $13.82 \%$ and $25.72 \%$ were recorded, respectively. Plant height recorded in subsoil after 90 days was in the range of $72.8 \mathrm{~cm}$ to $88.0 \mathrm{~cm}$, whereas that of topsoil was in the range of $70.3 \mathrm{~cm}$ to $84.0 \mathrm{~cm}$. The difference in plant growth between topsoil and subsoil could be due to the high levels of $\mathrm{Al}$ and $\mathrm{Pb}$ in topsoil. At $\mathrm{pH}$ lower than 5.5, $\mathrm{Al}$ becomes highly solubilized and poses phytotoxic threats [47]. Al toxicity causes lesions in plant roots, and subsequently, root growth inhibition leading to impaired nutrient uptake [48]. Similarly, $\mathrm{Pb}$ saturation is able to affect plant growth, morphology, physiological processes, and photosynthetic activity adversely [49]. This is depicted in Figure 2, where the roots of J. curcas grown in topsoil and subsoil were observed to be less well developed than that of the control (nursery soil). It was further supported by the root biomass result shown in Figure 3. Figure 3 shows that the root biomass of plants grown in nursery soil was significantly higher than that of topsoil and subsoil.

ANOVA revealed that the overall plant growth was significantly higher in nursery soil than topsoil and subsoil, but not significantly different between topsoil and subsoil. The result suggested that subsoil was able to support J. curcas growth without much inhibition, despite having a lower nutrient content than topsoil. Moreover, the plants did not exhibit water stress and nutrient disorder symptoms during the pot experiment, whereas these symptoms were shown by oil palms in the abandoned bauxite mine in Pengerang, Johor [15]. A positive growth performance in subsoil is a crucial prerequisite for rehabilitation in opencast bauxite mines as subsurface soils are exposed due to the disturbance of mine surface soils caused by the mining excavation activities [50].

As shown in Figure 4, plants growing in subsoil yielded more seeds than that of topsoil during the 90-day pot experiment period. Plants grown in subsoil yielded 1.89-fold more seeds than those grown in topsoil. This resulted in a total seed yield weighing at $7.614 \mathrm{~g}$ from subsoil, which was 1.63-fold heavier than that of topsoil. The resulting oil yield from the seed production is illustrated in Figure 5.

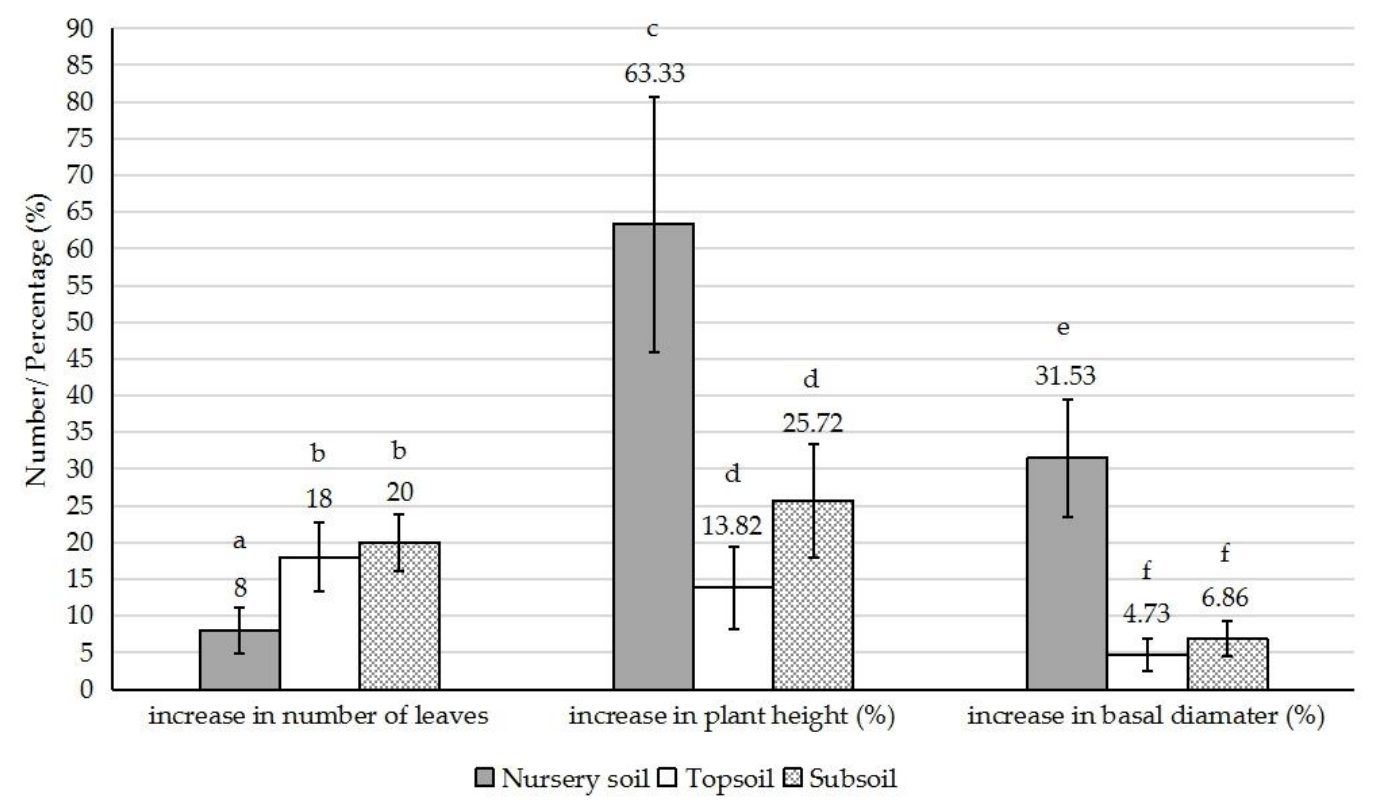

Figure 1. The overall growth of Jatropha curcas during the pot experiment. Different letters indicate that the means of each growth parameter between treatments were significantly different at $p<0.05$. Error bars indicate mean \pm standard deviation (SD) with five replicates. 


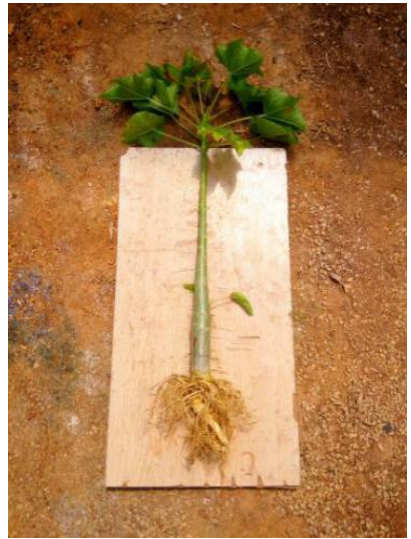

(a)

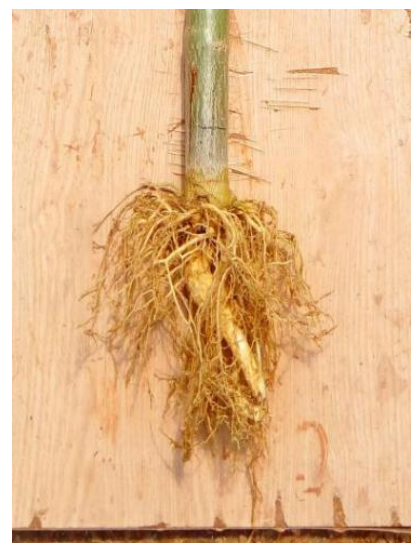

(d)

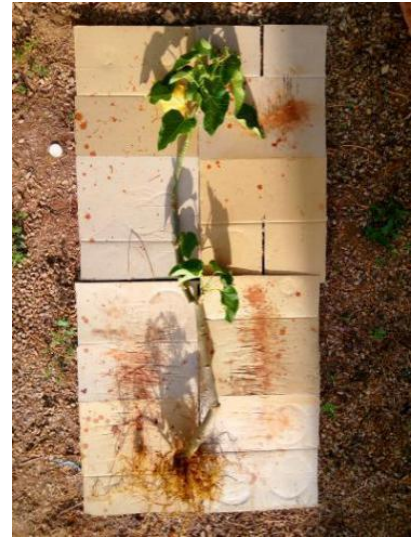

(b)

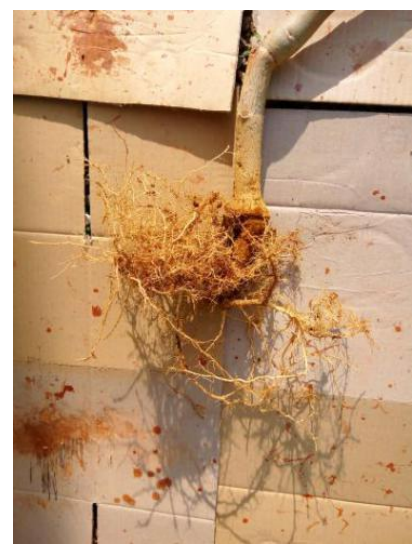

(e)

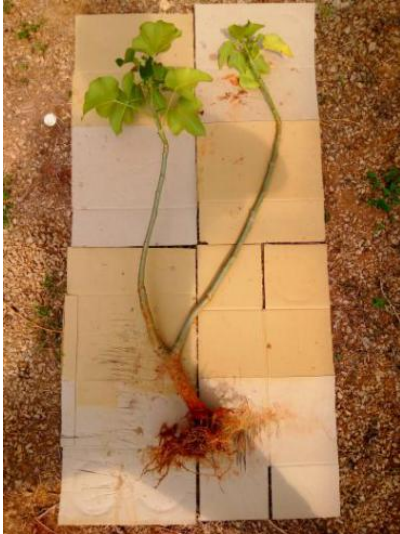

(c)

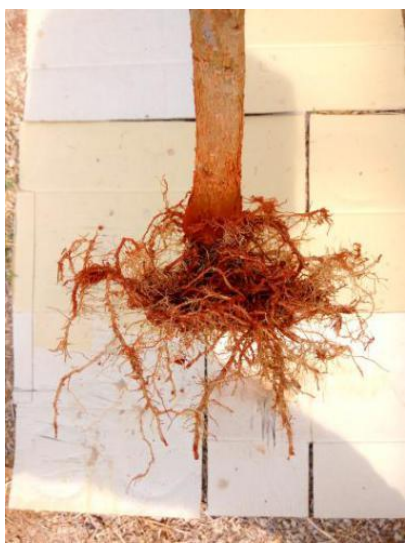

(f)

Figure 2. Upper left to right: J. curcas grown in (a) nursery soil, (b) bauxite mine topsoil, and (c) bauxite mine subsoil. Plants grown in topsoil and subsoil developed lateral branches, whereas nursery soil produced plants without lateral branching. Bottom left to right: J. curcas root grown in (d) nursery soil, (e) bauxite mine topsoil, and (f) bauxite mine subsoil. Plant roots grown in different soils exhibited different morphology.

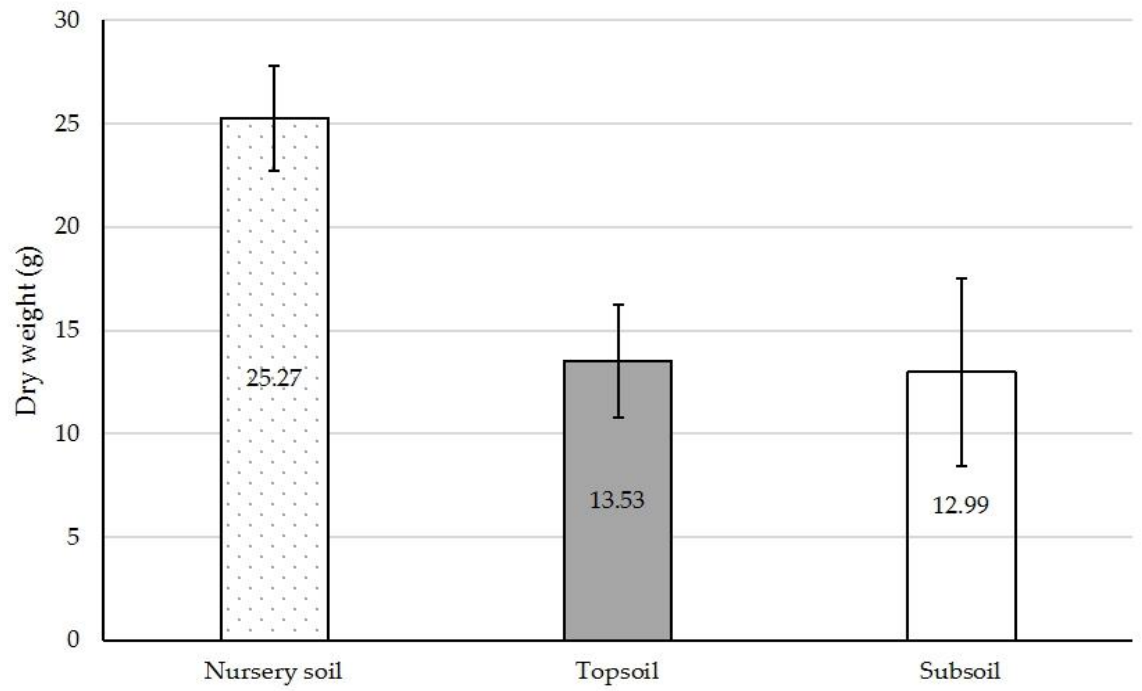

Figure 3. Root biomass of J. curcas grown in different soil. Error bars indicate mean \pm SD with five replicates. 


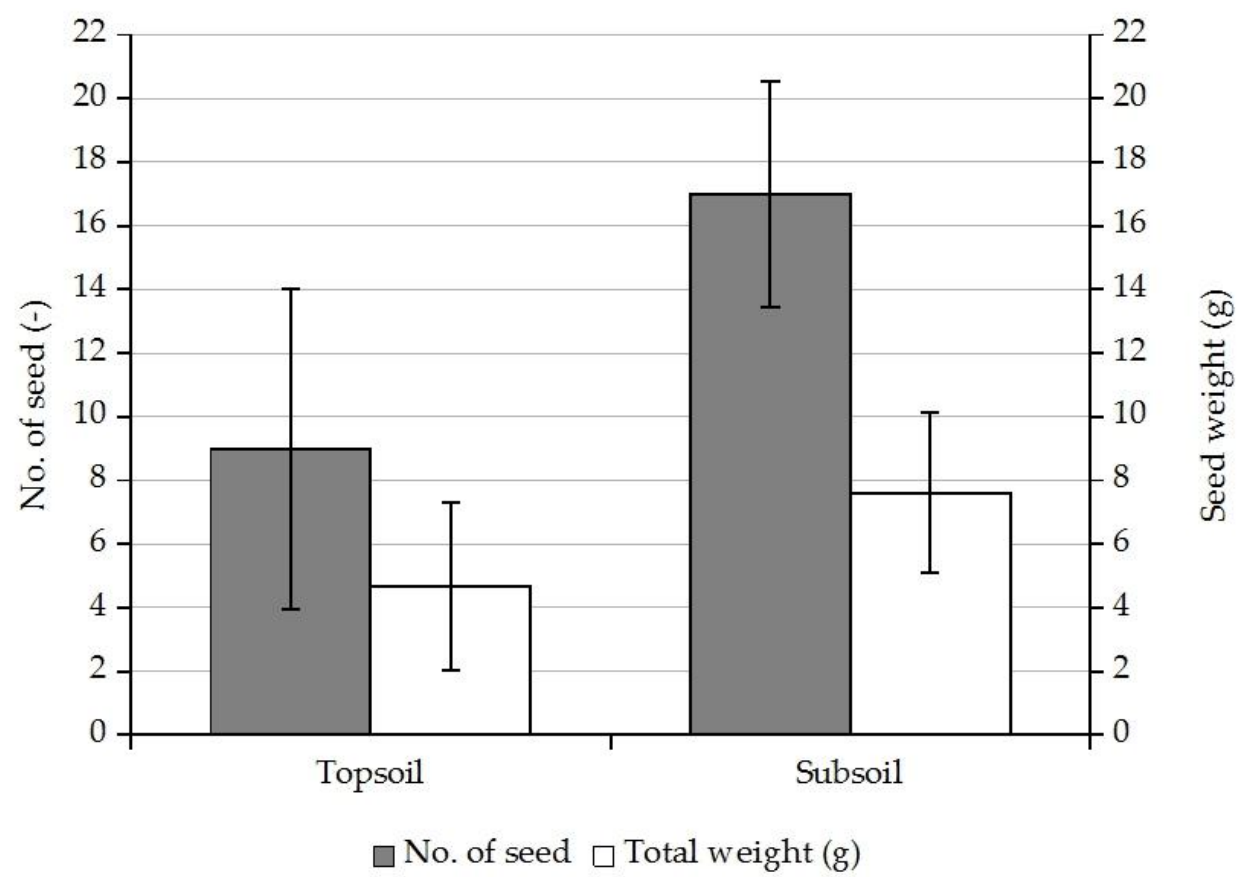

Figure 4. The average seed yield of plants grown in topsoil and subsoil over the course of 90 days. Error bars indicate mean \pm SD with five replicates.

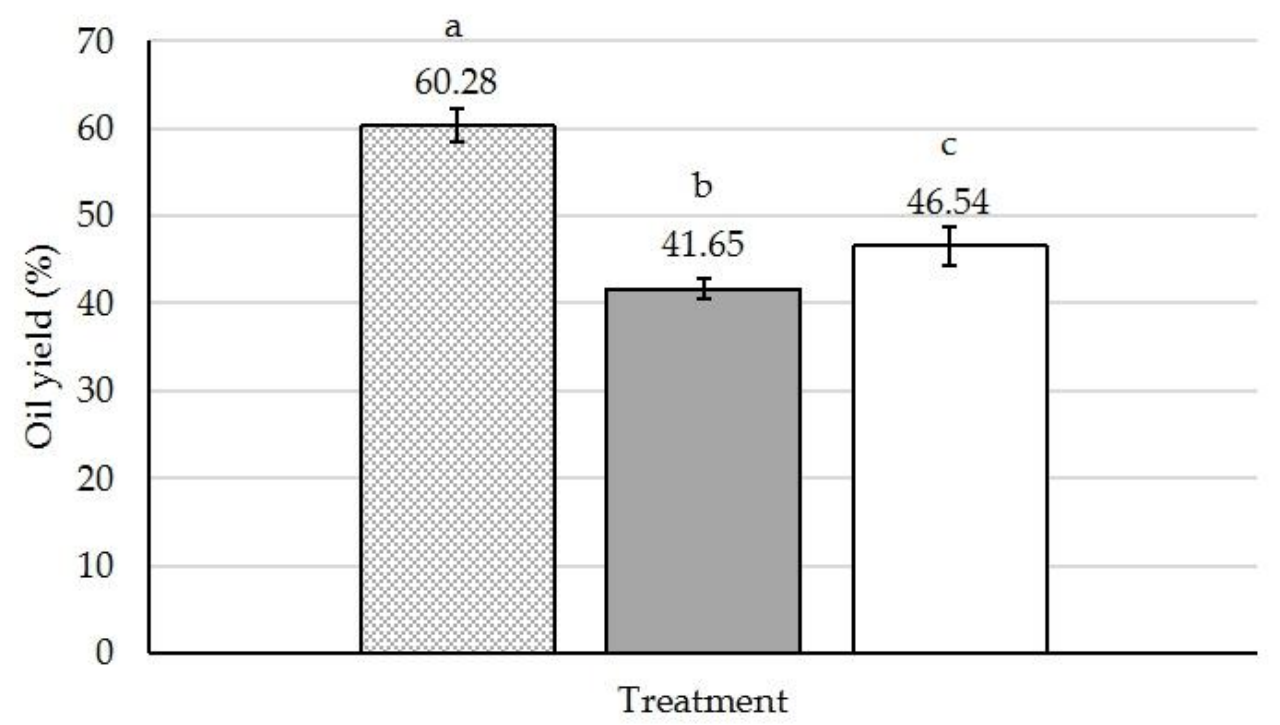

\section{$\square$ Control $\square$ Topsoil $\square$ Subsoil}

Figure 5. The oil yield extracted from the seeds harvested during the pot experiment period. Error bars indicate mean \pm SD with triplicates. Different letters indicate significantly different means between treatments.

J. curcas is an oil-producing crop that has garnered attention as an alternative fuel source, especially as a biodiesel feedstock. Its seed kernel contains fairly high oil content, which ranges from $45 \%$ to $60 \%$ by weight [51]. The kernel oil yield from the plants cultivated in topsoil $(41.65 \%)$ was lower than reported range, but that of subsoil fell within the reported range at $46.54 \%$. Based on the oil yield and total weight of seed yield, the plants cultivated in subsoil were able to generate a total oil production of $3.54 \mathrm{~g}$, as opposed to $1.95 \mathrm{~g}$ produced by those in topsoil throughout the pot experiment. Oil yield determined in this study varied with the results from other studies investigating on the oil yield of J. curcas cultivated in suboptimal conditions. Vaknin et al. [52] reported a relatively high oil yield 
ranging from $50.84 \%$ to $57.38 \%$ produced by the plants under semiarid conditions. In another study, J. curcas that was grown in arid areas of India had a lower oil production rate, which ranged from $25 \%$ to $41 \%$ [53]. The seed oil yield of J. curcas is highly variable due to several reasons like genetic variables, environmental factors, and agronomic procedures [54]. However, morphological traits like stem diameter can be used as an indicator tool for determining productive cultivars [55]. In this study, higher oil yield was produced by the plants cultivated in subsoil, which also showed a higher basal diameter growth than those cultivated in topsoil. A higher oil yield also indicates that the plants cultivated in subsoil had more advantage epigenetically as they bore a greater capacity in acclimatizing to their environment [56].

The impact of the heavy metal concentration in soil on plant performance was further investigated by analyzing the oil yield. Correlation and regression analyses were performed to evaluate the relationship between heavy metal concentration in soil and the plant oil yield, as depicted in Figure 6 . The concentration of $\mathrm{Al}$ and $\mathrm{Pb}$ were found to be significantly and negatively correlated with the plant oil yield. When the concentration of $\mathrm{Al}$ and $\mathrm{Pb}$ increases in soil, the plant oil yield decreases. In this study, this was demonstrated by the lower oil yield produced by the plants grown in topsoil, which contained higher amount of $\mathrm{Al}$ and $\mathrm{Pb}$ than subsoil. The observation was probably due to the plant toxicity caused by $\mathrm{Al}$ and $\mathrm{Pb}$, which affected the plant growth and physiological process as discussed above. Conversely, the concentration of Fe was found to be significantly and positively correlated to the plant oil yield. This means that plant oil yield increases with an increase in Fe concentration. This trend was exhibited in the higher oil yield produced by the plants grown in subsoil, which had a higher amount of Fe than topsoil. As a micronutrient, Fe might have a positive influence on J. curcas oil production as it has been reported to have played a crucial role in sunflower seed and oil production under normal and stress conditions [57].

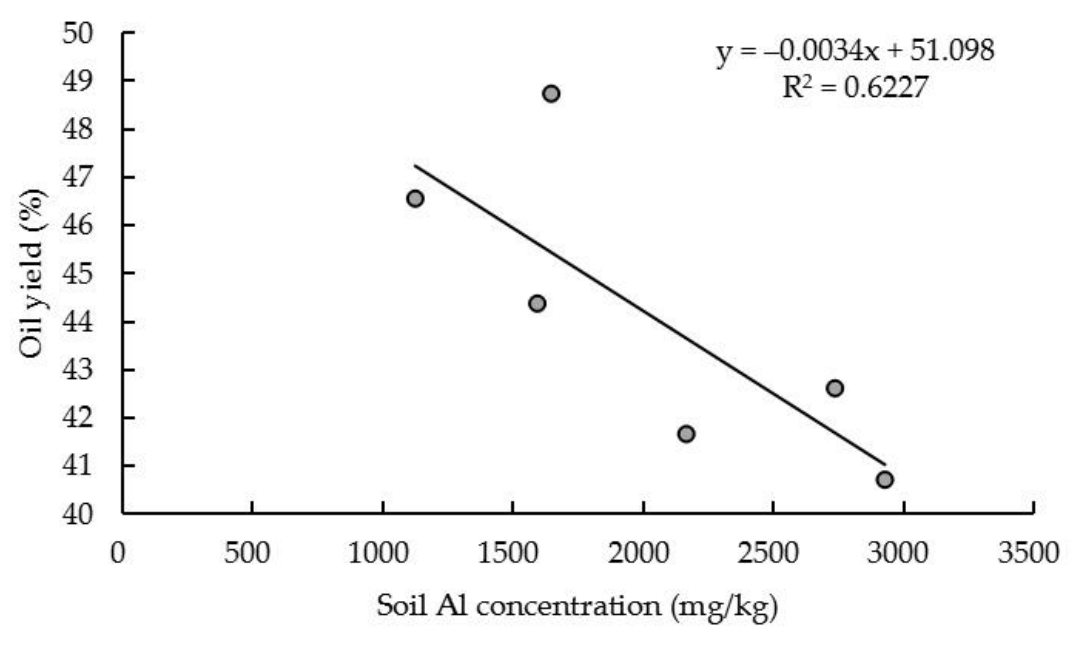

(a)

Figure 6. Cont. 


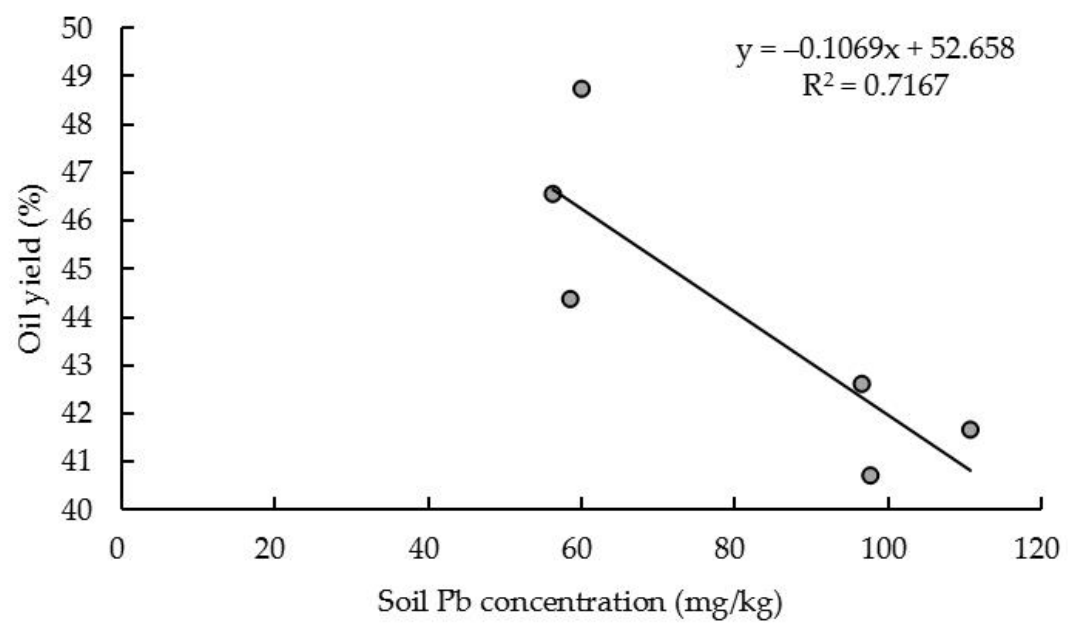

(b)

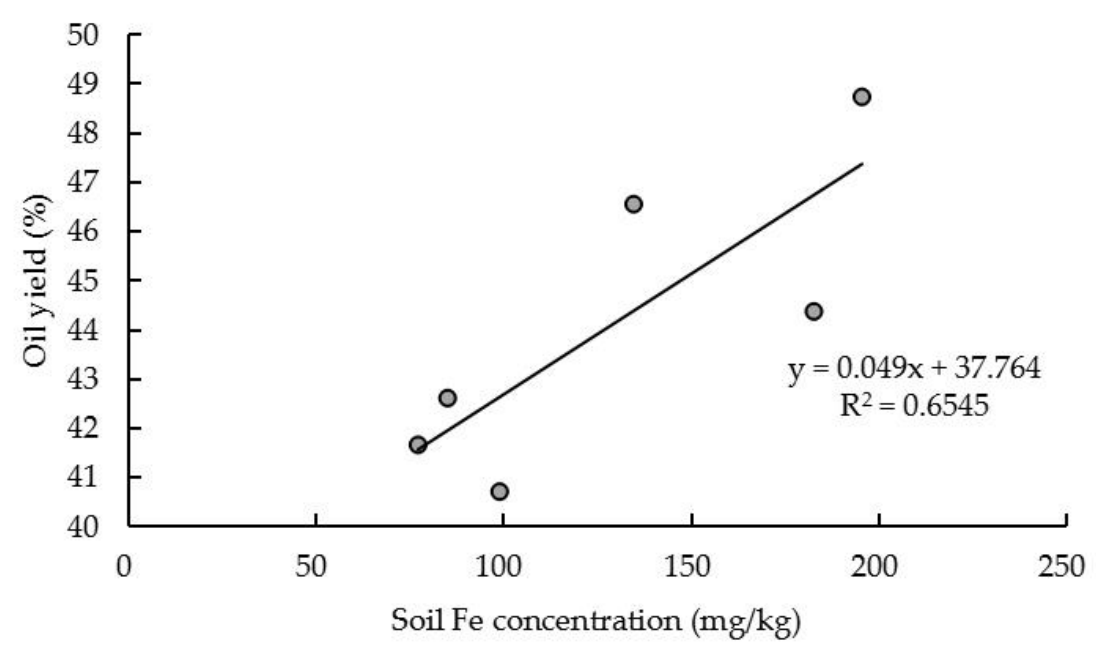

(c)

Figure 6. Scatterplots of (a) oil yield against Al concentration in soil, (b) oil yield against $\mathrm{Pb}$ concentration in soil, (c) oil yield against Fe concentration in soil, produced by plants grown in topsoil and subsoil. The relationship is significant at $p<0.05$.

\section{Conclusions}

This study looked at the characteristics of former bauxite mine soils and the growth performance of Jatropha curcas growing in them as a preliminary investigation into the feasibility of revegetating abandoned bauxite mines using J. curcas. Both topsoil and subsoil from the former bauxite mine were compared for their physicochemical properties. Both showed fairly low nutrient status and were considered as mildly acidic to acidic soil. $\mathrm{Al}, \mathrm{Fe}$, and $\mathrm{Pb}$ were among the heavy metals found in high levels in both soil types. Generally, J. curcas plants cultivated in bauxite mine soils had stunted growth rates relative to those cultivated in nursery soil. However, they still showed positive growth and encouraging oil yield. A higher seed oil yield was produced by the plants cultivated in subsoil as compared to topsoil, with a value of $46.54 \%$. The concentration of $\mathrm{Al}$ and $\mathrm{Pb}$ in soil were identified to be inversely proportional to the oil yield of J. curcas, whereas the concentration of Fe in soil was directly proportional to the oil yield of the plants. Future studies may explore means to increase the growth rate and oil yield of J. curcas growing on bauxite mine soils, e.g., through application of soil amendments. On the whole, the overall positive growth performance as exhibited by J.curcas in this 
study suggests that the plant has potential to be cultivated on local abandoned bauxite mine soil as a revegetation effort, as well as a rural development program that can generate economical returns.

Author Contributions: Conceptualization, L.M. and L.Y.P.; Methodology, L.M., A.W.S. and M.Y.S.; Software, L.M. and M.Y.S.; Validation, L.M. and L.Y.P.; Formal analysis, L.M. and A.W.S.; Investigation, L.M. and A.W.S.; Resources, A.W.S. and L.Y.P.; Data curation, L.M. and M.Y.S.; Writing-original draft, L.M.; Writing-review and editing, L.Y.P.; Supervision, A.W.S., M.Y.S and L.Y.P.; Project administration, L.M. and L.Y.P.; Funding acquisition, L.Y.P. All authors have read and agreed to the published version of the manuscript.

Funding: This research was funded by Universiti Putra Malaysia on an offer of Geran Universiti Putra Malaysia, GP-IPS/2017/9520300 and the APC was funded by Universiti Putra Malaysia as well.

Acknowledgments: The authors are grateful for the support and funding by Universiti Putra Malaysia under Geran Universiti Putra Malaysia, GP-IPS/2017/9520300. The authors would also like to express gratitude for the assistance provided by Faculty of Biotehnology and Biomolecular Sciences and Faculty of Agriculture from Universiti Putra Malaysia as well as FELDA Bukit Goh, Kuantan.

Conflicts of Interest: The authors declare no conflict of interest. The funders had no role in the design of the study; in the collection, analyses, or interpretation of data; in the writing of the manuscript, or in the decision to publish the results.

\section{References}

1. Shaheen, M.A.; Rana, S.I.; Tariq, M.I.; Rehman, F.; Karim, A.; Murtaza, N.A.S.; Aziz, M. Evaluation of Bauxite of Khushab (Pakistan) as a Raw Material for Extraction of Aluminum. Pak. J. Sci. 2010, 62, 79-83.

2. Kusin, F.M.; Rahman, M.S.A.; Madzin, Z.; Jusop, S.; Mohamat-Yusuff, F.; Ariffin, M.; Zahar, M.S.M. The Occurrence and Potential Ecological Risk Assessment of Bauxite Mine-impacted Water and Sediments in Kuantan, Pahang, Malaysia. Environ. Sci. Pollut. Res. 2017, 24, 1306-1321. [CrossRef] [PubMed]

3. Harris, M.A.; Omoregie, S.N. Post-mining Deterioration of Bauxite Overburdens in Jamaica: Storage Methods or Subsoil Dilution? Environ. Geol. 2008, 54, 111-115. [CrossRef]

4. Lewis, D.E.; White, J.R.; Wafula, D.; Athar, R.; Dickerson, T.; Williams, H.N.; Chauhan, A. Soil Functional Diversity Analysis of a Bauxite-Mined Restoration Chronosequence. Soil Microbiol. 2010, 59, 710-723. [CrossRef] [PubMed]

5. Ghose, M.K. Management of Topsoil for Geo-environmental Reclamation of Coal Mining Areas. Environ. Geol. 2001, 40, 1405-1410.

6. Salt, D.E.; Blaylock, M.; Kumar, N.P.B.A.; Dushenkov, V.; Ensley, B.D.; Chet, I.; Raskin, I. Phytoremediation: A Novel Strategy for the Removal of Toxic Metals from the Environment Using Plants. Nat. Biotechnol. 1995, 13, 468-474. [CrossRef] [PubMed]

7. Khalid, S.; Shahid, M.; Niazi, N.K.; Murtaza, B.; Bibi, I.; Dumat, C. A Comparison of Technologies for Remediation of Heavy Metal Contaminated Soils. J. Geochem. Explor. 2017, 182, 247-268. [CrossRef]

8. Gomes, H.I. Phytoremediation for Bioenergy: Challenges and Opportunities. Environ. Technol. Rev. 2012, 1, 59-66. [CrossRef]

9. Reddy, K.R.; Adams, J.A. Towards Green and Sustainable Remediation of Contaminated Site. In Proceedings of the 6th International Congress on Environmental Geotechnics, New Delhi, India, 8-12 November 2010.

10. Gautam, M.; Pandey, D.; Agrawal, M. Phytoremediation of Metals Using Lemongrass (Cymbopogon citratus (D.C.) Stapf.) Grown Under Different Levels of Red Mud in Soil Amended with Biowastes. Int. J. Phytoremediation 2017, 19, 555-562. [CrossRef] [PubMed]

11. Ghosh, M.; Singh, S.P. A Review on Phytoremediation of Heavy Metals and Utilization of Its By-products. Asian J. Energy Environ. 2005, 6, 214-231.

12. Alshaal, T.; Domokos-Szabolcsy, É.; Márton, L.; Czakó, M.; Kátai, J.; Balogh, P.; Elhawat, N.; El-Ramady, H.; Fári, M. Phytoremediation of Bauxite-derived Red Mud by Giant Reed. Environ. Chem. Lett. 2013, 11, 295-302. [CrossRef]

13. Milner, M.J.; Kochian, L.V. Investigating Heavy-metal Hyperaccumulation using Thlaspi caerulescens as a Model System. Ann. Bot. 2008, 102, 3-13. [CrossRef] [PubMed]

14. Mahar, A.; Wang, P.; Ali, A.; Awasthi, M.K.; Lahori, A.H.; Wang, Q.; Li, R.; Zhang, Z. Challenges and Opportunities in the Phytoremediation of Heavy Metals Contaminated Soils: A review. Ecotoxicol. Environ. Saf. 2016, 126, 111-121. [CrossRef] [PubMed]

15. Jusop, S. Bauxite Mining in Pengerang; Universiti Putra Malaysia Press: Serdang, Malaysia, 2016; 49p. 
16. Henning, R.K. Using the Indigenous Knowledge of Jatropha: The Use of Jatropha curcas Oil as Raw Material and Fuel. In IK Notes; World Bank: Washington, DC, USA, 2002; No. 47.

17. Openshaw, K. A Review of Jatropha curcas: An Oil Plant of Unfulfilled Promise. Biomass Bioenergy 2000, 19, 1-15. [CrossRef]

18. Kumar, A.; Sharma, S. An Evaluation of Multipurpose Oil Seed Crop for Industrial Uses (Jatropha curcas L.): A Review. Ind. Crops Prod. 2008, 28, 1-10. [CrossRef]

19. Ndong, R.; Montrejaud-Vignoles, M.; Girons, O.S.; Gabrielle, B.; Pirot, R.; Domergue, M.; Sablayrolles, C. Life Cycle Assessment of Biofuels from Jatropha curcas in West Africa: A Field Study. Glob. Chang. Biol. Bioenergy 2009, 1, 197-210. [CrossRef]

20. Agamuthu, P.; Abioye, O.P.; Abdul Aziz, A. Phytoremediation of Soil Contaminated with Used Lubricating Oil Using Jatropha curcas. J. Hazard. Mater. 2010, 179, 891-894. [CrossRef]

21. Ahmadpour, P.; Nawi, A.M.; Abdu, A.; Abdul-Hamid, H.; Singh, D.K.; Hassan, A.; Majid, N.M.; Jusop, S. Uptake of Heavy Metals by Jatropha curcas L. Planted in Soils Containing Sewage Sludge. Am. J. Appl. Sci. 2010, 7, 1291-1299.

22. Jamil, S.; Abhilash, P.C.; Singh, N.; Sharma, P.N. Jatropha curcas: A Potential Crop for Phytoremediation of Coal Fly Ash. J. Hazard. Mater. 2009, 172, 269-275. [CrossRef]

23. Majid, N.M.; Islam, M.M.; Riasmi, Y. Heavy Metal Uptake and Translocation by Jatropha curcas L. in Sawdust Sludge Contaminated Soils. Aust. J. Crop Sci. 2012, 6, 891-898.

24. Chang, F.-C.; Ko, C.-H.; Tsai, M.-J.; Wang, Y.-N.; Chung, C.-Y. Phytoremediation of Heavy Metal Contaminated Soil by Jatropha curcas. Ecotoxicology 2014, 23, 1969-1978. [CrossRef] [PubMed]

25. Goswami, K.; Saikia, J.; Choudhury, H.K. Economic Benefits and Costs of Jatropha Plantation in North-East India. Agric. Econ. Res. Rev. 2011, 24, 99-108.

26. Soil and Plant Analysis Council. Soil Analysis: Handbook of Reference Methods; CRC Press: Boca Raton, FL, USA, 2000; 247p.

27. Jimenez, R.R.; Ladha, J.K. Automated Elemental Analysis: A Rapid and Reliable but Expensive Measurement of Total Carbon and Nitrogen in Plant and Soil Samples. Commun. Soil Sci. Plant Anal. 1993, 24, 1897-1924. [CrossRef]

28. Sapeta, H.; Costa, J.M.; Lourenço, T.; Maroco, J.; van der Linde, P.; Oliveira, M.M. Drought Stress Response in Jatropha curcas: Growth and Physiology. Environ. Exp. Bot. 2013, 85, 76-84. [CrossRef]

29. Giwa, S.O.; Yahaya, S.; Ibrahim, M.; Giwa, A. Extraction of Oil from Jatropha Seed Kernels: Optimization and Characterization. Int. J. ChemTech Res. 2016, 9, 758-770.

30. Fauziah, C.I.; Jamilah, I.; Syed Omar, S.R. An Evaluation of Cation Exchange Capacity Methods for Acid Tropical Soils. Pertanika J. Trop. Agric. Sci. 1997, 20, 113-119.

31. Sanchez, P.A.; Palm, C.A.; Buol, S.W. Fertility Capability Soil Classification: A Tool to Help Assess Soil Quality in the Tropics. Geoderma 2003, 114, 157-185. [CrossRef]

32. Cation Exchange Capacity and Base Saturation. Available online: https://extension.uga.edu/publications/ detail.html?number=C1040\&title=Cation\%20Exchange $\% 20$ Capacity $\% 20$ and $\% 20 B a s e \% 20$ Saturation\#: \{\} : text=Depending\%20on\%20soil\%20pH\%2C\%20the,saturation \%20is\%20equal\%20to\%20CEC (accessed on 6 April 2020).

33. Saini, J.; Grewal, K.S. Vertical Distribution of Different Forms of Potassium and Their Relationship with Different Soil Properties in Some Haryana Soil under Different Crop Rotation. Adv. Plants Agric. Res. 2014, 1, 48-52. [CrossRef]

34. Yadav, B.K.; Sidhu, A.S. Dynamics of Potassium and Their Bioavailability for Plant Nutrition. In Potassium Solubilizing Microorganisms for Sustainable Agriculture; Meena, V., Maurya, B., Verma, J., Meena, R., Eds.; Springer: New Delhi, India, 2016; pp. 187-201.

35. Afari-Sefa, V.; Kwakye, P.K.; Nyamiah, M.; Okae-Anti, D.; Imoro, A.Z. Potassium Availability in Soils—Forms and Spatial Distribution; International Atomic Energy Agency (IAEA): Vienna, Austria, 2004; p. 20.

36. Sarkar, G.K.; Chattopadhyay, A.P.; Sanyal, S.K. Release Pattern of Non-exchangeable Potassium Reserves in Alfisols, Inceptisols and Entisols of West Bengal, India. Geoderma 2013, 207-208, 8-14. [CrossRef]

37. Peck, N.H.; MacDonald, G.E.; Vittum, M.T.; Lathwell, D.J. Effects of Concentrated Superphosphate and Potassium Chloride on Residual Available P, K, and Cl in Three Depths of Soil Derived from Calcareous Glacial Till. Agron. J. 1976, 68, 504-506. [CrossRef] 
38. Sharpley, A.N.; Smith, S.J. Distribution of Potassium Forms in Virgin and Cultivated Soils of the U.S.A. Geoderma 1988, 42, 317-329. [CrossRef]

39. Zheng, S.J. Crop Production on Acidic Soils: Overcoming Aluminium Toxicity and Phosphorus Deficiency. Ann. Bot. 2010, 106, 183-184. [CrossRef] [PubMed]

40. Ministry of Housing, Spatial Planning and Environment Directorate-General for Environmental Protection. Circular on Target Values and Intervention Values for Soil Remediation; Netherlands Government Gazette: Dutch, The Netherlands, 2000; pp. 1-8.

41. Mathiyazhagan, N.; Natarajan, D. Phytoremediation Efficiency of Edible and Economical Crops on Waste Dumps of Bauxite Mines, Salem District, Tamil Nadu, India. In On a Sustainable Future of the Earth's Natural Resources; Ramkumar, M., Ed.; Springer: Berlin/Heidelberg, Germany, 2013; pp. 493-508.

42. Mathiyazhagan, N.; Natarajan, D. Impact of Mine Waste Dumps on Growth and Biomass of Economically Important Crops. J. Environ. Biol. 2012, 33, 1069-1074. [PubMed]

43. Rahim, F.A.A.; Hamid, T.H.T.A.; Zainuddin, Z. Jatropha curcas as a Potential Plant for Bauxite Phytoremediation. IOP Conf. Ser. Earth Environ. Sci. 2019, 308, 012006. [CrossRef]

44. Kleiman, D.; Aarssen, L.W. The Leaf Size/Number Trade-off in Herbaceous Angiosperms. J. Ecol. 2007, 95, 376-382. [CrossRef]

45. Dombroskie, S.L.; Aarssen, L.W. The Leaf Size/Number Trade-off within Species and Within Plants for Woody Angiosperms. Plant Ecol. Evol. 2012, 145, 38-45. [CrossRef]

46. Dombroskie, S.L.; Tracey, A.J.; Aarssen, L.W. Leafing Intensity and the Fruit Size/Number Trade-off in Woody Angiosperms. J. Ecol. 2016, 104, 1759-1767. [CrossRef]

47. Delhaize, E.; Ryan, P.R. Aluminum Toxicity and Tolerance in Plants. Plant Physiol. 1995, 107, $315-321$. [CrossRef]

48. Kopittke, P.M.; Moore, K.L.; Lombi, E.; Gianoncelli, A.; Ferguson, B.J.; Blamey, F.P.C.; Menzies, N.W.; Nicholson, T.M.; McKenna, B.A.; Wang, P.; et al. Identification of the Primary Lesion of Toxic Aluminum in Plant Roots. Plant Physiol. 2015, 167, 1402-1411. [CrossRef]

49. Yadav, S. Heavy Metals Toxicity in Plants: An Overview on the Role of Glutathione and Phytochelatins in Heavy Metal Stress Tolerance of Plants. S. Afr. J. Bot. 2010, 76, 167-179. [CrossRef]

50. Lad, R.J.; Samant, J.S. Impact of Bauxite Mining on Soil: A Case Study of Bauxite Mines at Udgiri, Dist-Kolhapur, Maharashtra State, India. Int. Res. J. Environ. Sci. 2015, 4, 77-83.

51. Pramanik, K. Properties and Use of Jatropha curcas Oil and Diesel Fuel Blends in Compression Ignition Engine. Renew. Energy 2003, 28, 239-248. [CrossRef]

52. Vaknin, Y.; Yermiyahu, U.; Bar-Tal, A.; Samocha, Y. Global Maximization of Jatropha Oil Production Under Semi-arid Conditions by Balancing Vegetative Growth with Reproductive Capacity. Glob. Chang. Biol. Bioenergy 2017, 10, 382-392. [CrossRef]

53. Kumar, S.; Shukla, S.D.; Gautam, P.K.; Kato, S.; Kojima, T. Effect of Climate and Soil Condition on Oil Content of Jatropha Plants Grown in Arid Areas of India. J. Arid Land Stud. 2011, 21, 51-55.

54. Lama, A.D.; Klemola, T.; Saloniemi, I.; Niemelä, P.; Vuorisalo, T. Factors Affecting Genetic and Seed Yield Variability of Jatropha curcas (L.) Across the Globe: A Review. Energy Sustain. Dev. 2018, 42, 170-182. [CrossRef]

55. Laviola, B.G.; Alves, A.A.; Rocha, R.B.; Drumond, M.A. The Importance of Jatropha for Brazil. In Jatropha, Challenges for a New Energy Crop; Carels, N., Sujatha, M., Bahadur, B., Eds.; Springer: New York, NY, USA, 2012; Volume 1, pp. 71-94.

56. Latzel, V.; Allan, E.; Bortolini Silveira, A.; Colot, V.; Fischer, M.; Bossdorf, O. Epigenetic Diversity Increases the Productivity and Stability of Plant Populations. Nat. Commun. 2013, 4, 2875. [CrossRef]

57. Ebrahimian, E.; Bybordi, A. Effect of Iron Foliar Fertilization on Growth, Seed and Oil Yield of Sunflower Grown under Different Irrigation Regimes. Middle-East J. Sci. Res. 2011, 9, 621-627.

(C) 2020 by the authors. Licensee MDPI, Basel, Switzerland. This article is an open access article distributed under the terms and conditions of the Creative Commons Attribution (CC BY) license (http://creativecommons.org/licenses/by/4.0/). 